\title{
PENGARUH PENGGUNAAN APLIKASI CHEMDRA W SEBAGAI SUMBER BELAJAR KIMIA TERHADAP PENINGKATAN HASIL BELAJAR MAHASISWA PADA MATERI SPEKTROSKOPI NMR
}

\author{
Krisna Utami ${ }^{1 *}$, Julina Wati ${ }^{2}$, Sella Veronika ${ }^{3}$, Retno Widy Astuti ${ }^{4}$, Rahimuddin ${ }^{5}$ \\ ${ }_{1,2,3,4,5}$ Program Studi Pendidikan Kimia, FKIP Universitas Samudra \\ Jln. Kampus Meurandeh, Langsa - Aceh 24416 \\ *Email:krisnautami42@gmail.com
}

\begin{abstract}
ABSTRAK
Tujuan dari penelitian ini adalah untuk mengetahui pengaruh penggunaan aplikasi ChemDraw sebagai sumber belajar kimia terhadap peningkatan hasil belajar mahasiswa pada materi Spektroskopi NMR di Universitas Samudra. Metode yang digunakan dalam penelitian ini adalah menggunakan metode preeksperimen dengan desain penelitian one group pretest posttest. Sampel yang dipilih adalah mahasiswa pendidikan kimia semester 5 berjumlah 15 orang dengan perlakuan pembelajaran menggunakan aplikasi ChemDraw pada materi Spektroskopi NMR. Teknik pengumpulan data dilakukan melalui tes tertulis, yakni berupa soal pretest dan posttest berbentuk essay. Data hasil tes dianalisis dengan menggunakan rumus uji $t$ berpasangan, Effect size dan $N$-Gain. Berdasarkan hasil pehitungan, pada uji $t$ diperoleh nilai $\mathrm{t}_{\text {hitung }}>\mathrm{t}_{\text {tabel }}$ yakni 4,94 >1,75 dengan nilai signifikan $0,00<0,05$ sehingga $\mathrm{H}_{0}$ ditolak dan $\mathrm{H}_{\mathrm{a}}$ diterima. Dari data uji effect size yang diperoleh sebesar 1, 27 yakni termasuk kategori kuat, dan pada analisis $N$-Gain diperoleh rerata peningkatan hasil belajar sebesar 0,6 yakni termasuk kategori sedang. Dari hasil uji $t$ berpasangan dan Effect size dapat disimpulkan bahwa adanya pengaruh yang kuat dalam penggunaan aplikasi ChemDraw pada materi spektroskopi NMR terhadap peningkatan hasil belajar mahasiswa pendidikan kimia Universitas Samudra. Dari hasil analisis $N$-Gain dapat disimpulkan bahwa adanya peningkatan hasil belajar mahasiswa dengan menggunakan aplikasi ChemDraw pada materi Spektroskopi NMR yang berkategori sedang.
\end{abstract}

Kata Kunci: Aplikasi ChemDraw, hasil belajar, spektroskopi NMR

\begin{abstract}
The purpose of this research to determine the effect of using the ChemDraw application as a study resource of learning outcomes for chemical students in NMR Spectroscopy material at Samudra University. The method of this research use a pre-experimental method with one group pretest postest research design. The sample chosen was $5^{\text {th }}$ semester of chemistry education students of totaling 15 people with the learning treatment using ChemDraw application on NMR Spectroscopy material. Data collection techniques were carried out through written tests are pretest and posttest questions in the form of essays. The test of result data were analyzed using the paired T test formula, Effect size and N-Gain. Based on the calculation results, the paired $T$ test it can be concluded that there is an influence of the use of the ChemDraw application on NMR spectroscopy material of learning outcomes for the $5^{\text {th }}$ semester of chemistry education students at Samudra University. Based on the results obtained $t_{\text {count }}>t_{\text {table }}$ which is $4.94>1.75$ with a significant value of $0.00<0.05$ so that $H_{0}$ is rejected and $H_{a}$ is accepted. From the effect size test data obtained is 1, 27, the meaning of including the strong category, and the N-Gain analysis obtained an average increase in learning outcomes of 0.6, including the medium category. From the results of the paired t test and Effect size it can be concluded that there is a strong influence in the use of ChemDraw application on NMR spectroscopy material to improve learning outcomes of students of chemistry education at Samudra University. From the results of the $\mathrm{N}$-Gain analysis it can be concluded that there is an increase in student learning outcomes using the ChemDraw application in the NMR Spectroscopy material which is of medium category.
\end{abstract}

Keywords: ChemDraw application, learning outcomes, NMR spectroscopy 


\section{PENDAHULUAN}

Dewasa ini sering kita mendengar istilah "Revolusi Industri 4.0" pada abad 21, bahkan kita dikatakan telah memasuki era tersebut. Perkembangan dunia abad 21 ditandai dengan adanya pemanfaatan teknologi informasi dan komunikasi dalam segala aspek kehidupan, termasuk dalam proses pembelajaran (Pratiwi et al., 2018). Perkembangan ini mengarah pada perubahan yang semakin signifikan menuju era praktis. Pada sektor pendidikan, perkembangan teknologi informasi merambah pada sistem pengelolaan dan juga sistem pembelajaran di kelas. Pemanfaatan media yang semakin bervariasi menjadi tantangan bagi setiap pendidik dalam melaksanakan tugasnya di sekolah/perguruan tinggi dalam rangka mencapai tujuan pembelajaran (Purbasari, et al., 2012).

Media merupakan sarana untuk menyalurkan pesan atau informasi dalam belajar yang ingin disampaikan oleh sumber pesan kepada penerima pesan (Mahnun, 2012). Manfaat dari penggunaan media yaitu dapat mengefektifkan komunikasi dan interaksi antara pendidik dengan peserta didik ketika proses pembelajaran (Setiyorini et al, 2016). Jika media pembelajaran yang digunakan pendidik kurang efektif dan efisien, maka berdampak pada tidak seimbangnya kompetensi peserta didik baik dari segi kognitif, afektif dan psikomotoriknya. Beberapa penyebab dari kurang efektif dan efisiennya suatu media yang digunakan pendidik antara lain: Pembelajaran yang selalu monoton, sifat pendidik yang otoriter (sewenang-wenang), serta pendidik yang kurang bersahabat dengan peserta didiknya. Tentu saja hal ini akan menyebabkan peserta didik merasa jenuh serta minatnya untuk belajar menjadi berkurang, sehingga akan berdampak pada hasil belajarnya. Salah satu bidang ilmu yang sangat memerlukan adanya penggunaan media pembelajaran adalah Kimia. Hal ini dikarenakan kimia merupakan bidang ilmu yang bersifat abstrak.

Salah satu perangkat yang digunakan sebagai media pembelajaran berbasis teknologi dan informatika adalah komputer, dengan software Chem Office yang berisi berbagai macam aplikasi dan salah satunya adalah ChemDraw. Aplikasi ChemDraw berisi berbagai macam fitur kimia yang dibutuhkan oleh pendidik dalam mengajar dan menyelesaikan tugas Kegiatan Belajar Mengajar (KBM)-nya (Pratiwi et al., 2018).

Dalam mempelajari bidang ilmu Kimia, ada beberapa kesulitan yang sering dihadapi oleh peserta didik, seperti pemahaman konsep, penggambaran struktur, perhitungan dan lainnya (Subagia, 2014). Salah satu materi kimia yang sulit dipahami oleh peserta didik, khususnya mahasiswa adalah Spektroskopi NMR.

Spektroskopi Resonansi Magnetik Inti atau Nuclear Magnetic Resonance (NMR) merupakan salah satu metode spektroskopi yang sangat bermanfaat dalam penentuan struktur suatu senyawa kimia, baik proton $\left({ }^{1} \mathrm{H}\right)$ maupun karbon $\left({ }^{13} \mathrm{C}\right)$ NMR. Metode ini didasarkan pada momen magnet dari inti atom. Inti tertentu menunjukkan perilaku seolah-olah mereka berputar (spin). Bila inti dengan spin diletakkan di antara kutub-kutub magnet yang sangat kuat, inti akan menjajarkan medan magnetikya sejajar (paralel) atau melawan (antiparalel) medan magnetik (Harold, 2003). Dengan demikian, penggunaan media pembelajaran dengan aplikasi ChemDraw sangat diperlukan dalam menunjang pemahaman mahasiswa terkait penentuan struktur pada materi Spektroskopi NMR, sehingga dapat mempengaruhi peningkatan hasil belajarnya. Berdasarkan uraian diatas penelitian ini bertujuan untuk melihat 
pengaruh penggunaan aplikasi ChemDraw sebagai sumber belajar kimia terhadap peningkatan hasil belajar mahasiswa pada materi Spektroskopi NMR di Universitas Samudra”.

\section{METODE}

Penelitian ini dilakukan di Universitas Samudra, Langsa. Rancangan penelitian ini yaitu pre-eksperimental dengan design one group pretest posttest. Sampel yang dipilih adalah mahasiswa pendidikan kimia semester 5 yang berjumlah 15 orang dengan perlakuan pembelajaran menggunakan aplikasi ChemDraw pada materi Spektroskopi NMR.

Metode yang digunakan untuk pengumpulan data adalah metode tes tertulis. Metode tes menggunakan instrumen berupa soal essay yang bertujuan untuk mengetahui pengaruh aplikasi ChemDraw terhadap hasil belajar mahasiswa. Penelitian ini dilakukan melalui beberapa tahap yaitu tahap pemberian pretest hal ini dilakukan sebelum diberi perlakuan, kemudian tahap perlakuan yaitu dengan menampilkan aplikasi ChemDraw dan cara penggunaanya, tahap tetakhir yaitu pemberian posttest dengan menggunakan aplikasi ChemDraw.

Data yang diperoleh dari penelitian diolah menggunakan program SPSS Versi 21,0 yang digunakan untuk menghitung Uji $\mathrm{t}$ dan Effect Size. Analisis data yang diperoleh dari penelitian ini berupa nilai pretest, nilai posttest dan $\mathrm{N}$-Gain. Hasil analisis perhitungan $\mathrm{N}$-Gain dapat dijelaskan berdasarkan interpretasi dari Hake.Adapun interpretasinya dapat dituliskan sebagai berikut:

Tabel 1. Kategori Gain Ternormalisasi

\begin{tabular}{|l|c|}
\hline \multicolumn{1}{|c|}{ Nilai N-Gain } & Interpretasi \\
\hline $\mathrm{g}>0,7$ & Tinggi \\
\hline $0,3<\mathrm{g} \leq 0,7$ & Sedang \\
\hline $\mathrm{g} \leq 0,3$ & Rendah \\
\hline
\end{tabular}

Penggunaan SPSS versi 21,0 tidak hanya menganalisis hasil uji t berpasangan, tetapi juga harus melihat daftar distribusi $t_{\text {tabel }^{-}}$ nya. Menurut Sudjana (2005), kriteria pengujiannya adalah jika $t_{\text {tabel }}>t_{\text {hitung }}$, maka $\mathrm{H}_{0}$ diterima. Namun jika $t_{\text {hitung }}>t_{\text {tabel }}$, maka $\mathrm{H}_{0}$ ditolak. Untuk melihat pengaruh penggunaan aplikasi ChemDraw maka dapat di uji menggunakan Uji Effect size, yang dapat dirumuskan sebagai berikut:

$$
d=\frac{\overline{X 1}-\overline{X 2}}{S g a b}
$$

Hasil perhitungan effect size diinterpretasikan dengan menggunakan klasifikasi sebagai berikut:

Tabel 2. Klasifikasi Effect Size

\begin{tabular}{|c|c|}
\hline Besar $d$ & Interpretasi \\
\hline $0,0-0,2$ & Lemah \\
\hline $0,2-0,5$ & Cukup \\
\hline $0,5-1,0$ & Sedang \\
\hline$>1,0$ & Kuat \\
\hline
\end{tabular}

Pengujian ini bertujuan untuk mengetahui pengaruh dan seberapa besar pengaruh penggunaan aplikasi ChemDraw terhadap peningkatan hasil belajar mahasiswa pada materi Spektroskopi NMR.

Gambar 1. Aplikasi ChemDraw

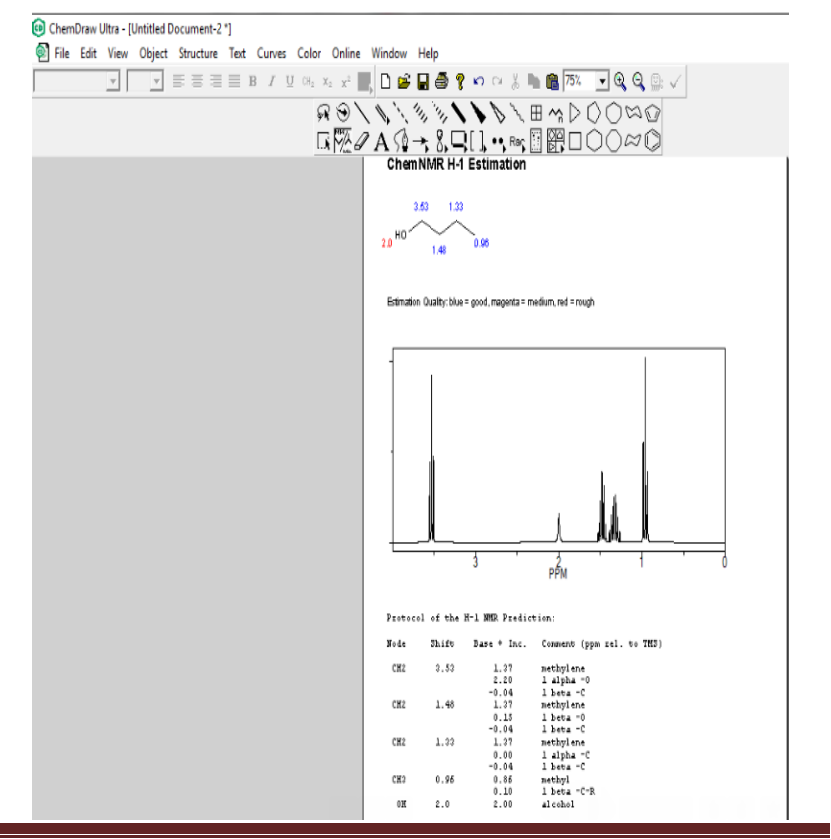

KATALIS Jurnal Penelitian Kimia dan Pendidikan Kimia Vol. 3, No. 1, Juni 2020 


\section{HASIL DAN PEMBAHASAN}

Metode pengumpulan data yang digunakan dalam penelitian ini adalah metode tes berupa pretest dan posttest yang mencakup materi spektroskopi NMR. Pada tahap pretest, ditemukan fakta bahwa mahasiswa kesulitan dalam menentukan struktur suatu senyawa dari sebuah spektrum yang telah diberikan. Hal ini dikarenakan materi penentuan struktur NMR merupakan salah satu materi yang abstrak. Pada tahap pemberian postest, mahasiswa lebih mudah dalam menentukan suatu struktur yang juga dilengkapi langsung dengan spektrum dan data hasil pergeseran kimia dari suatu senyawa dengan menggunakan aplikasi ChemDraw.

\section{Gambar 2. Proses Penggunaan Aplikasi} ChemDraw

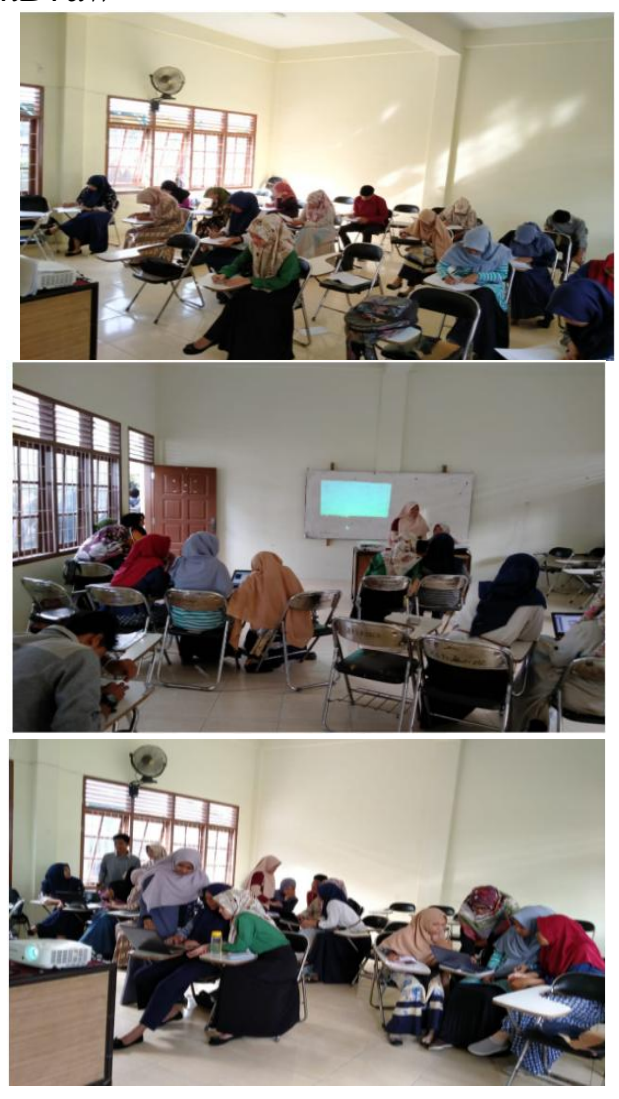

Peneliti ingin melihat pengaruh peningkatan hasil belajar masiswa dalam materi penentuan struktur NMR menggunakan aplikasi ChemDraw. Hasil data pretest dan posttest yang didapatkan akan dianalisis menggunakan uji t (t-test) dan uji $N$-Gain. Hake 1998, memperkenalkan $N$-Gain sebagai tolak ukur dari efektifitas kursus dalam mempromosikan konseptual. N-Gain merupakan suatu uji yang dapat menggambarkan secara umum peningkatan nilai yang diperoleh dari hasil pembelajaran dilihat dari sebelum dan sesudahnya diterapkan metode tersebut.

Dengan menggunakan uji N-Gain, peneliti dapat mengetahui perbedaan nilai kemampuan mahasiswa yang dilihat dari peningkatan maupun penurunan hasil belajarnya, sehingga analisis ini cocok untuk diterapkan sebagai penentuan adanya pengaruh dari definisi tersebut, sehingga analisis $\mathrm{N}$-Gain cocok untuk diterapkan dalam menentukan ada tidaknya pengaruh peningkatan hasil belajar mahasiswa dengan menggunakan media aplikasi ChemDraw. Analisis ini dilakukan dengan menggunakan rumus gain yang ternormalisasi karena dianggap lebih efektif sebagai berikut:

Indeks Gain $(\mathrm{g})=\frac{\text { skor postest }- \text { skor pretest }}{\text { skor ideal }- \text { skor pretest }}$

Menghitung $\mathrm{N}$-Gain bertujuan untuk menghindari adanya kesalahan dalam menginterpretasikan perolehan gain dari nilai hasil belajar mahasiswa sebelum maupun setelah diberikan perlakuan dengan menggunakan aplikasi ChemDraw. Adapun hasil $N$-Gain yang diperoleh setelah melakukan penelitian adalah:

Tabel 3. Hasil perbandingan nilai pretest, postest dan $N$-Gain

\begin{tabular}{|c|c|c|c|c|c|}
\hline No. & Nama & Pretest & Postest & $\begin{array}{c}\text { N- } \\
\text { gain }\end{array}$ & Kategori \\
\hline 1 & $\mathrm{~A}_{1}$ & 65 & 90 & 0,7 & Sedang \\
\hline 2 & $\mathrm{~A}_{2}$ & 70 & 80 & 0,3 & Sedang \\
\hline 3 & $\mathrm{~A}_{3}$ & 70 & 80 & 0,3 & Sedang \\
\hline 4 & $\mathrm{~A}_{4}$ & 65 & 90 & 0,7 & Sedang \\
\hline
\end{tabular}




\begin{tabular}{|c|c|c|c|c|c|}
\hline 5 & $\mathrm{~A}_{5}$ & 75 & 90 & 0,6 & Sedang \\
\hline 6 & $\mathrm{~A}_{6}$ & 50 & 95 & 0,9 & Tinggi \\
\hline 7 & $\mathrm{~A} 7$ & 80 & 80 & 0,0 & Rendah \\
\hline 8 & $\mathrm{~A}_{8}$ & 45 & 100 & 1,0 & Rendah \\
\hline 9 & $\mathrm{~A}_{9}$ & 65 & 100 & 1,0 & Rendah \\
\hline 10 & $\mathrm{~A}_{10}$ & 70 & 100 & 1,0 & Rendah \\
\hline 11 & $\mathrm{~A}_{11}$ & 20 & 80 & 0,8 & Tinggi \\
\hline 12 & $\mathrm{~A}_{12}$ & 70 & 80 & 0,3 & Sedang \\
\hline 13 & $\mathrm{~A}_{13}$ & 70 & 80 & 0,3 & Sedang \\
\hline 14 & $\mathrm{~A}_{14}$ & 80 & 90 & 0,5 & Sedang \\
\hline 15 & $\mathrm{~A}_{15}$ & 70 & 80 & 0,3 & Sedang \\
\hline \multicolumn{2}{|l|}{ Jumlah } \\
\hline \multicolumn{2}{|l}{ Rata-rata } & & 8,8 & \\
\hline
\end{tabular}

Berdasarkan data tabel diatas, diperoleh hasil $\mathrm{N}$-Gain untuk kategori rendah berjumlah 4 orang, kategori sedang berjumlah 9 orang dan kategori tinggi berjumlah 2 orang. Hasil akhir diperoleh bahwa rata-rata nilai $N$-Gain mahasiswa adalah 0,6. Hal ini menunjukkan bahwa terdapat peningkatan hasil belajar mahasiswa semester 5 pendidikan kimia di Universitas Samudra dengan menggunakan media aplikasi ChemDraw terhadap materi spektroskopi NMR dengan kategori "sedang".

Tabel 4. Rata- Rata Nilai Pretest dan Posttest

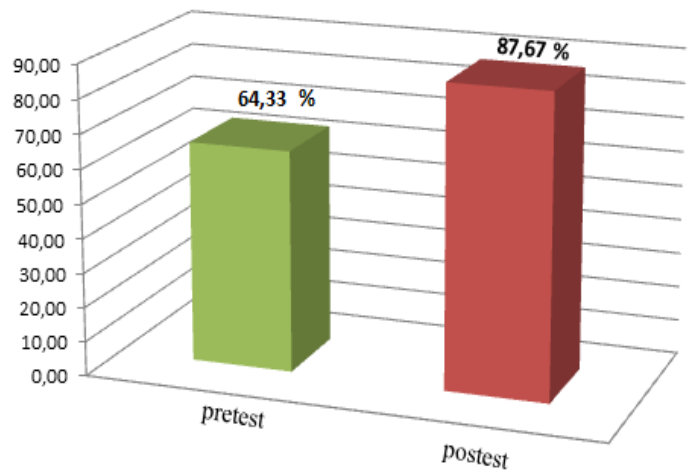

Grafik diatas menunjukkan bahwa nilai rata-rata pretest sebesar $64,33 \%$ dan rata-rata posttest sebesar $87,67 \%$, sehingga diperoleh nilai rata-rata $N$-Gain sebesar 0,6 yang artinya nilai Gain ternormalisasi dengan kategori “sedang" (Sudjana, 2012).

\section{Tabel 5. uji t}

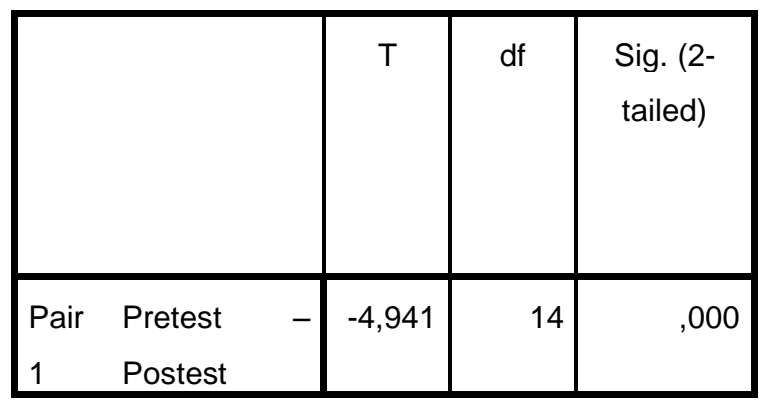

Berdasarkan tabel diatas diperoleh hasil analisis uji $\mathrm{t}$ berpasangan dengan menggunakan SPSS versi 21,0, dimana diketahui bahwa nilai $t_{\text {tabel }}$ untuk df 14 adalah

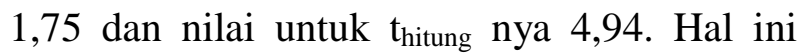
menunjukkan bahwa $t_{\text {hitung }}>t_{\text {tabel }}$ yang dimana hipotesis untuk uji $\mathrm{t}$ berpasangan sebagai berikut:

Ho : Tidak ada pengaruh penggunaan aplikasi ChemDraw pada materi spektroskopi NMR terhadap hasil belajar mahasiswa semester 5 pendidikan kimia Universitas Samudra Langsa.

Ha : Terdapat pengaruh penggunaan aplikasi ChemDraw pada materi spektroskopi NMR terhadap hasil belajar mahasiswa semester 5 pendidikan kimia Universitas Samudra.

Keputusan diambil dengan kriteria sebagai berikut:

Jika sig $<0,05$ maka Ho ditolak

Jika sig > 0,05 maka Ha diterima

Dari hasil analisis uji t diperolehpada tabel diatas diketahui bahwa $t_{\text {tabel }}>t_{\text {hitung }}$ yaitu $4,94>1,75$ dengan nilai signifikannya $0,00<$ 0,05 sesuai dengan kriteria maka Ho ditolak dan $\mathrm{Ha}$ diterima dimana terdapat pengaruh penggunaan aplikasi ChemDraw pada materi spektroskopi NMR terhadap hasil belajar mahasiswa semester 5 pendidikan kimia Universitas Samudra, Langsa. Dari data uji effect size yang diperoleh sebesar 1, 27, menunjukkan bahwa penggunaan aplikasi ChemDraw pada materi spektroskopi NMR memiliki pengaruh yang kuat terhadap 
peningkatan hasil belajar mahasiswa pendidikan kimia.

Hal ini pun didukung oleh penelitian sebelumnya yang dilakukan oleh (yuanita dkk,2018) penggunaan aplikasi ChemDraw efektif dalam membantu mempelajari bidang kimia, khususnya untuk para guru dalam meningkatkan pemahaman dan minat dalam mempelajari kimia. Penelitian oleh (Ratih, dkk 2018) yang menyatakan bahwa aplikasi ChemDraw dapat diterapkan sebagai bahan ajar student centered berbasis informatika.

ChemDraw adalah salah satu fitur dari ChemOffice yaitu salah satu produk dari raksasa perusahaan bidang kimia Perkin Elmer dan Cambridge Software yang memiliki berbagai fitur dalam menggambar struktur molekul serta berbagai fitur yang sangat menarik yang akan membuat metode pembelajaran menjadi lebih variatif dan menarik (Parkin, 2018).

Media aplikasi ChemDraw dapat mempengaruhi peningkatkan hasil belajar mahasiswa, karena media ChemDraw ini mampu melatih mahasiswa untuk mereview mata pelajaran secara terus-menerus khususnya spektroskopi NMR. Berdasarkan pengamatan yang dilakukan, mahasiswa terlihat aktif dan bersemangat dalam belajar. Hal tersebut dapat dilihat dari antusiasme mahasiswa saat menjawab soal posttest yang diberikan.

Mahasiswa mengalami kesulitan dalam mata pelajaran spektroskopi NMR diantaranya pemahaman konsep, memahami dan membayangkan struktur molekul, membaca spektrum dan lainnya. Terlihat bahwa membayangkan struktur dan membaca spektrum merupakan bagian yang paling sulit yang dirasakan oleh mahasiswa. Hal ini tidak mengherankan karena, dalam bidang kimia sendiri objek yang dikaji adalah sesuatu yang sangat mikroskopik dan abstrak. Oleh karena itu, melalui penelitian ini diharapkan mampu mengatasi hal tersebut, sehingga membantu mahasiswa dalam mengilustrasikan bentuk struktur dan membaca spektrum.

\section{UCAPAN TERIMA KASIH}

Peneliti mengucapkan terima kasih kepada seluruh mahasiswa semester 5 program studi pendidikan kimia Universitas Samudra yang telah terlibat didalam penelitian ini, serta seluruh mahasiswa pendidikan kimia 2016 yang ikut membantu suksesnya kegiatan ini.

\section{KESIMPULAN}

Hasil penelitian ini, dapat disimpulkan bahwa penggunaan aplikasi ChemDraw pada materi spektroskopi NMR memiliki pengaruh terhadap peningkatan hasil belajar mahasiswa dengan kategori sedang. Hal ini dapat dilihat dari hasil analisis yang diperoleh pada uji $\mathrm{T}$ berpasangan yakni $t_{\text {hitung }}=4,94>t_{\text {tabel }}=1,75$ dengan nilai signifikan $0,000<0,05$ yang berarti $\mathrm{H}_{0}$ ditolak dan $\mathrm{H}_{\mathrm{a}}$ diterima serta hasil analisis $N$-Gain yang diperoleh dengan nilai rata-rata sebesar 0,6 dengan kategori sedang.

\section{DAFTAR PUSTAKA}

Hake, R., R. (1999). Analyzing Change/Gain Scores. AREA-D American Education Research Association's Devision. D, Measurement and Reasearch Methodology.

Harold, Hart. 2003. Kimia Organik. Jakarta:s Erlangga.

Mahnun, N. 2012. Media Pembelajaran (Kajian terhadap Langkah-langkah Pemilihan Media dan Implementasinya dalam Pembelajaran). Jurnal Pemikiran Islam, 37(1): 27-35.

Parkin, Elmer. 2018. ChemOffice Professional. Diambil kembali dari Parkin Elmer 
Product:

http://www.parkinelmer.com/chemofficeprofessional-chemofficepro.

Pratiwi, R. H., Endang, S., dan Fery, R. 2018. Pendampingan Aplikasi ChemDraw untuk Meningkatkan Kemampuan Guru dalam Menerapkan Bahan Ajar Student Centered Berbasis Informatika. Jurnal Publikasi Pendidikan, 8 (3): 186-193.

Purbasari, R., Kahfi, M. dan Yunus, M. 2012. Pengembangan Aplikasi Android sebagai Media Pembelajaran Matematika pada Materi Dimensi Tiga untuk Siswa SMA Kelas X. Jurnal Pendidikan Matematika, 1(2): 3-11.

Setiyorini., S. P., dan N. A. N. Murniati. (2016). Pengembangan Media Pembelajaran Moodle. Jurnal Penelitian Pembelajaran Fisika. 7 (2): 156-160.

Subagia, I. W. 2014. Paradigma Baru Pembelajaran Kimia SMA. Seminar Nasional FMIPA UNDIKSHA, 152-163.

Sudjana, Nana. (2005). Metoda Statistika. Bandung: PT Tarsito.

Yuanita, E., Sudirman, Maria, U., dan Ni, K. T. D. E. 2018. Aplikasi Chemdraw Dan Avogadro Untuk Meningkatkan Pemahaman dan Minat Dalam Bidang Kimia. Jurnal Pendidikan dan Pengabdian Masyarakat, 1(2): 209-214. 